\title{
LEMAH SANAD BELUM TENTU LEMAH MATAN
}

\author{
Arief Muammar \\ Program Studi Ilmu Alquran dan Tafsir Fakultas Ushuluddin Adab dan Dakwah IAIN Langsa \\ Kampus Zawiyah Cot Kala Jl. Meurandeh, Langsa, 24411, Aceh, Indonesia \\ Email: ariefmuammar@iainlangsa.ac.id
}

\begin{abstract}
This study discusses about the rule is not necessarily weak sanad weak matan hadith is a rule that applies only to the weak hadith. The rules of tradition of this kind can be used with the following conditions: first, the support strength of other traditions his matan matching, narrated of narrators (sanad path) to another, as well as the quality is equal or better than the first chain of transmission paths. Second, the narrators do not be evil, or a liar, nor a forger of hadith and is not known as one who fahusya galațhu (many false) and inattentive, not al-muttahimina bil kaziib (accused of lying), not heretical and not majḥul 'ain. Third, Hadith da 'if not too weak as mursal hadith, mu'allal, and mubham. So the traditions are not too weak, they could still acceptable (maqbül) if there is a path sanad from another hadith. Fourth, the hadith-hadith has a martyr and mutābi', meaning not only narrated the hadith with a chain of transmission lines, because it could conflict with the rules that have been understandable, as the hadith matrūk.
\end{abstract}

Keywords: Sanad, Matan, Da'îf, I'tibār

\begin{abstract}
Abstrak
Kajian ini membahas seputar kaidah lemah sanad belum tentu lemah matan hadis merupakan kaidah yang hanya berlaku untuk hadis da'îf. Kaidah hadis semacam ini bisa digunakan dengan syarat: pertama, mendapat dukungan kekuatan dari hadis lain yang senada matannya, diriwayatkan dari perawi (jalur sanad) yang lain, serta kualitasnya pun sama atau lebih baik dari jalur sanad yang pertama. Kedua, perawinya tidak bersifat fasik, atau pendusta, bukan pula pemalsu hadis dan tidak dikenal sebagai orang yang fahusya galațhu (banyak salah) dan lalai, bukan al-muttahimīna bil każib (dituduh berdusta), bukan ahli bidah serta bukan majḥul 'ain. Ketiga, keḍ 'îfannya tidak terlalu lemah seperti hadis mursal, mu'allal, dan mubham. Maka hadis-hadis yang tidak terlalu lemah tersebut masih bisa diterima (maqbūl) jika ada jalur sanad dari hadis yang lain. Keempat, hadishadisnya memiliki syāhid dan mutābi', maksudnya hadis tersebut tidak hanya diriwayatkan dengan satu jalur sanad saja, karena bisa bertentangan dengan kaidah-kaidah yang sudah dimaklumi, seperti hadis matrūk.
\end{abstract}

Kata Kunci: Sanad, Matan, Da 'îf, I'tibār

\section{Pendahuluan}

Hadis menempati posisi kedua setelah Alquran dalam sumber hukum Islam, kaum muslimin diperintahkan oleh Allah dan Rasul-Nya untuk selalu tunduk dan patuh di bawah naungan Alquran dan Hadis dalam setiap dinamika kehidupan. Untuk memahami kualitas atau status hadis, maka kita harus mempersiapkan bekal utama yaitu seputar ilmu hadis dan perangkat-perangkat ilmu lainnya yang mendukung proses pengetahuan mengenai hadis, bahkan ada dua unsur penting untuk mengidentifikasikan kualitas suatu hadis yaitu sanad dan matan, kedua unsur tadi dianggap sangat urgen oleh para ulama hadis dalam objek kajian mereka, karena dengan adanya jalur periwayatan yang 
orisinal dan otentik inilah; khususnya periwayatan yang sampai kepada Nabi saw, makanya Islam memiliki ribuan keistimewaan (kelebihan) dibandingkan agama-agama lainnya di muka bumi.

Pembahasan mengenai klasifikasi hadis berdasarkan kualitas sanad dan matannya, tentu sangat menarik untuk dikaji lebih intensif, sehingga nantinya kita bisa menentukan status suatu hadis, apakah hadis tersebut bisa diterima (sahih dan hasan) atau ditolak (da îf $)$, bahkan yang menjadi pertanyaan mendasar adalah, dapatkah matan hadis da'if diaplikasikan meskipun telah terbukti isnād-nya lemah dalam rangkaian sanad suatu hadis? Itulah yang menjadi pokok bahasan dari tulisan ini.

Hadis da'îf yang disebabkan oleh lemahnya unsur periwayatan (jalur sanad suatu hadis), tidak serta-merta langsung ditolak untuk dijadikan hujah, karena boleh jadi sanadnya memang lemah, tapi dari segi matannya belum tentu mengindikasikan lemah, terlebih lagi jika ada jalur periwayatan beragam yang saling menguatkan satu hadis dengan yang lainnya, apa lagi jumlah turuq-nya (jalurjalur sanad) itu banyak, maka status hadis yang lemah tadi bisa berubah menjadi $m a q b \bar{u} l$ atau bisa terangkat menjadi hadis hasan ligairih (perpaduan antara beberapa hadis da îf yang diriwayatkan dari banyak jalur sanad karena ada syāhid dan tābi"nya).

Pembahasan di atas dikenal dengan kaidah, "Da'îf (lemah) isnād tidak menentukan pula da 'if matannya”. Kaidah ini tentunya berlaku untuk direalisasikan, tetapi setelah melewati beberapa ketentuan atau syarat yang telah disepakati oleh ulama pakar hadis. Di dalam artikel ini, penulis juga akan memaparkan definisi sanad dan matan yang disertai dengan contohcontohnya, begitu juga dengan perbedaan antara musnad, musnid dan isnād serta definisi hadis da'iff dan bentuk-bentuk $i$ 'tibār hadis. Mudah-mudahan artikel ini bisa menambah wawasan keilmuan para pembaca, khususnya dalam objek kajian hadis.

\section{Definisi Sanad dan Matan}

1. Pengertian Sanad

Sanad secara etimologi (kebahasaan) berarti:

1.)Al-mu 'tamad (الُمعَنَعَدُ), yaitu, “Yang dipedomani atau sesuatu yang bisa dijadikan pegangan".

2.)مَا ارْنَفَعَ مِنَ الْأَْْضِ yaitu, “sesuatu yang terangkat (tinggi) dari tanah". 2

${ }^{1}$ Muhammad bin Abī Bakr bin Abd al-Qādir al-Rāzī, Mukhtār Al-Ṣiḥhāh (Beirūt: Dār al-Fikr, 2003), 297.

${ }^{2}$ M. 'Ajjāj al-Khațīb, Ușūl al-Hadīṣ: 'Ulūmuhu wa Muștalāḥuhu (Beirūt: Dār al-Fikr, 
Sanad dari segi terminologi, berarti:

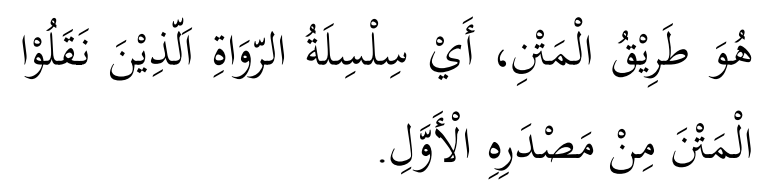

Sanad adalah jalannya matan, yaitu silsilah para perawi yang memindahkan (meriwayatkan) matan dari sumbernya yang pertama. ${ }^{3}$

Al-Ṭaḥanāwī mengemukakan definisi yang hampir senada seperti yang dikutip oleh Nawir Yuslem yaitu:

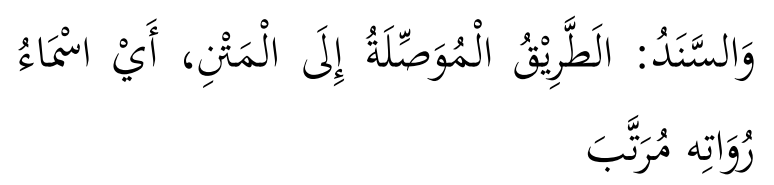

Dan sanad adalah jalan yang menghubungkan kepada matan hadis, yaitu nama-nama perawinya secara berurutan. ${ }^{4}$

Jadi, sanad itu merupakan jalan penghubung antara perawi-perawi yang meriwayatkan matan (teks) hadis dari sumbernya yang pertama.

Berikut ini adalah contoh hadis yang terdapat dalam kitab Sunan Al-Tirmizì . Adapun contoh sanad hadisnya yaitu:

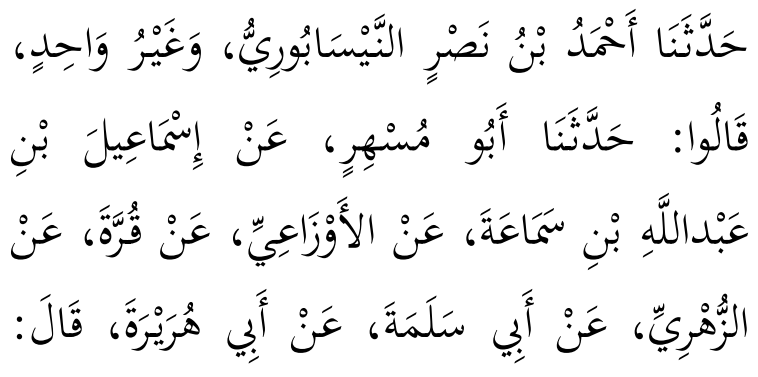

1989), 32. Nawir Yuslem, Ulumul Hadis (Jakarta: PT. Mutiara Sumber Widya, 2010), 148.

${ }^{3}$ Yuslem, Ulumul, 148.

${ }^{4}$ Yuslem, Ulumul, $149 . \quad$ Al-Ṭahānawī, Qawā' 'id fì 'Ulūm al-Hadīṣ, 26.

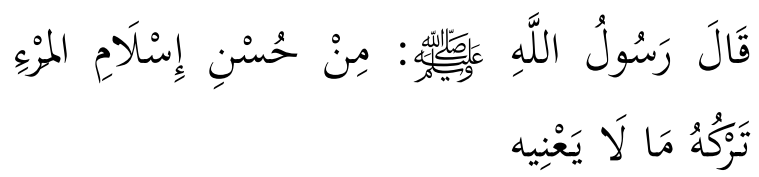

Kami diceritakan oleh Ahmad bin Nasar al-Naisaburi dan orang lain, mereka berkata, "Abu Mushir menceritakan kepada kami yang diriwayatkan dari Ismail bin Abdullah bin Sama'ah, dari alAuza'i, dari Qurrah, dari al-Zuhri, dari Abu Salamah Dari Abu Hurairah, beliau berkata, Rasullah saw bersabda" Diantara kebaikan seorang muslim adalah meninggalkan hal-hal yang tidak bermanfaat baginya". 5

Dari keterangan hadis di atas terlihat adanya silsilah para perawi hadis yang membawa kita kepada teks hadis yaitu Ahmmad bin Nashar al-Naisaburi, Abu Mushir, Ismail bin Abdullah bin Sama'ah, al-Auza'i, Qurrah, al-Zuhri, Abu Salamah, dan Abu Hurairah. Silsilah atau rangkaian nama-nama itulah yang dinamai dengan sanad dari hadis di atas, karena mereka-lah yang menjadi jalan bagi kita untuk sampai kepada matan (teks) hadis dari sumbernya yang pertama yaitu Nabi saw.

\section{Definisi Matan}

Definisi matan secara etimologi adalah: مَا صَلُبَ وَارَتَفَعَ مِنَ الْأَرْضِ yang berarti,

${ }^{5}$ Diriwayatkan oleh al-Tirmizī, Sunan alTirmizī, jilid 4 (Beirūt: Dār al-Fikr, 1403H / 1983 M), 559. No: 2318.

${ }^{6}$ Al-Rāzī, Mukhtār, 556. Lihat juga Mahmūd Al-Ṭaḥhān, Taysīr, 15. Al-Khațīb, Ușūl, 32. 
"Sesuatu yang keras dan tinggi (terangkat) dari bumi (tanah)".

Adapun definisi matan secara

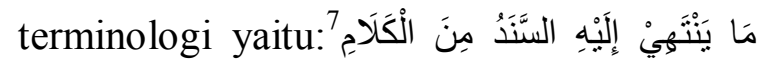
"Sesuatu yang berakhir (terletak setelah) sanad yaitu berupa perkataan". Matan menurut Nawir Yuslem yang beliau nukilkan dari 'Ajjāj al-Khațīb adalah: هُ

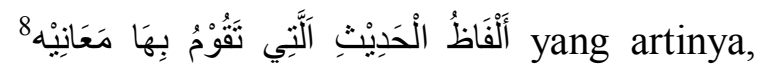
"lafal hadis yang mengandung makna (pengertian)".

Contoh matan ialah seperti sabda Nabi saw. berikut ini:

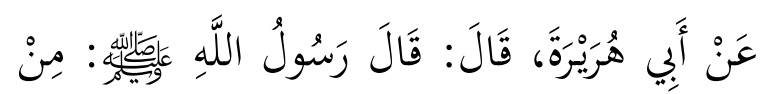

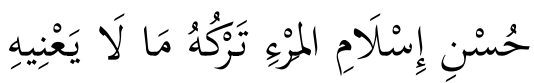

Dari Abu Hurairah, beliau berkata, Rasullah saw., bersabda: "Di antara kebaikan seorang muslim adalah meninggalkan hal-hal yang tidak bermanfaat baginya"

Lafaz yang terkandung dalam hadis di atas mulai dari kata min husni islām sampai kepada tarkuhu mālā ya'nīhn̄ disebut dengan matan (teks) hadis. Karena lafal hadis tersebut memiliki makna atau pengertian yang bisa dimengerti oleh pembaca ataupun pendengar.

\section{Perbedan Isnād, Musnid dan Musnad}

1. Isnād secara etimologi berarti menyandarkan sesuatu kepada yang

\footnotetext{
${ }^{7}$ Al-Khațīb, Ușūl, 32

${ }^{8} \mathrm{Al}-\mathrm{Khatị̄}$, Ușūl, 32.
}

lain. $^{9}$ Dengan arti lain upaya menerangkan hadis yang disertai dengan sanadnya. ${ }^{10}$ Sedangkan menurut istilah,

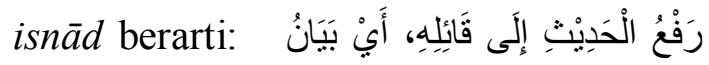
طَرِيْقِ "Mengangkat hadis kepada yang mengatakannya (sumbernya), yaitu menjelaskan jalan matan dengan meriwayatkan hadis secara bersanad". Contohnya adalah sebagai berikut:

حَدَّتَنَا أَحْمَدُ بْنُ نَصْرِ النََّْْسابُورِيُّ، وَغَيْرِ

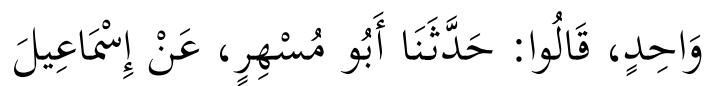
بْنِ عَبْداللَّهِ بْنِ سَمَاعَةَ، عَنْ الأَوْزَاعِيِّ، عَنْ

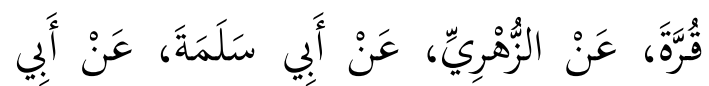

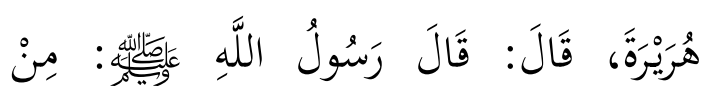

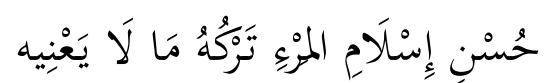

Kami diceritakan oleh Ahmad bin Nasar al-Naisaburi dan orang lain, mereka berkata, "Abu Mushir menceritakan kepada kami yang diriwayatkan dari Ismail bin Abdullah bin Sama'ah, dari al-Auza'i, dari Qurrah, dari al-Zuhri, dari Abu Salamah Dari Abu Hurairah, beliau berkata, Rasullah saw bersabda "Di antara kebaikan seorang muslim adalah meninggalkan hal-hal yang tidak bermanfaat baginya.

2. Musnid menurut bahasa yaitu sesuatu yang menyandarkan. Maḥmūd al-Ṭaḥḥān mendefinisikan musnid dengan

\footnotetext{
${ }^{9}$ Yuslem, Ulumul,152.

${ }^{10}$ Ramli Abdul Wahid, al-Qāmūs al-Muḥịt fi 'Ulūm al-Hadīs Kamus Lengkap Ilmu Hadis (Medan: Perdana Publishing, 2011), 87.

${ }^{11}$ Al-Khațīb, Ușūl, 32. Lihat juga al-Ṭaḥhān, Taysìr, 15. Yuslem, Ulumul, 152.
} 
pengertian: هُوَ مَنْ يَرْوِي الْحَدِيْتَ بِسَنَدِهِ سَوَاءُ

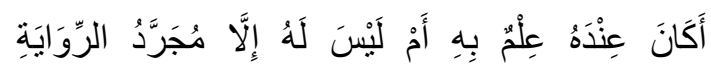
(musnid adalah orang yang meriwayatkan hadis lengkap dengan sanadnya, baik ia menguasai seluk beluk tentang hadis atau hanya semata-mata meriwayatkan hadis tersebut). ${ }^{12}$

Contohnya seperti Imam Ahmad bin Hanbal, Imam al-Nasa'i dan Abu Dawud.

3. Kata musnad adalah bentuk mufrad dari masānīd. Menurut bahasa ialah sesuatu yang disandarkan. Menurut terminologi ilmu hadis, musnad adalah kitab yang memuat hadis-hadis berdasarkan nama sahabat yang meriwayatkannya dari Rasul tanpa memperhatikan masalah yang dibicarakan hadis itu. Kitab terkenal tentang musnad adalah Musnad al-Imām Ahmad ibn Hanbal. ${ }^{13}$

Selain pengertian di atas, menurut Ramli Abdul Wahid yang beliau kutip dari kitab Taysīr Muṣtalāh al-Hadīs. Musnad juga memiliki beberapa pengertian di antaranya:

a. Hadis yang bersambung sanadnya dari awal sanad hingga akhir sanad sampai kepada Nabi saw.

${ }^{12}$ Al-Ṭaḥhān, Taysīr, 17, Wahid, al-Qāmūs, 164. Lihat juga Ramli Abdul Wahid, Studi Ilmu Hadis (Bandung: CitaPustaka Media Perintis, 2011), 24. Yuslem, Ulumul, 154. 154.

${ }^{13}$ Wahid, al-Qāmūs, 163. Yuslem, Ulumul, b. Setiap hadis marfī' (riwayat yang disandarkan kepada Nabi) dengan sanad yang bersambung.

c. Hadis yang menerangkan rangkaian sanadnya.

d. Semakna dengan pengertian sanad. ${ }^{14}$

\section{Hadis Da $a^{\prime} \bar{u} f$ dan I'tibār}

Hadis bila ditinjau dari segi kualitas sanad dan matannya dapat dibedakan menjadi dua golongan yakni: Hadis maqbūl dan hadis mardūd. ${ }^{15}$ Hadis maqbūl adalah hadis yang dapat diterima dan dijadikan sebagai hujah. Hadis maqbūl ini terdiri atas hadis sahih dan hadis hasan. Sementara yang dimaksud dengan hadis mardūd adalah hadis yang tidak bisa dijadikan hujah atau tidak memenuhi syarat-syarat qabūl, dan hadis mardūd dinamai juga dengan hadis $d a{ }^{\prime} i f f^{16}$

\section{Hadis $\underline{\text { Da }}{ }^{\top} \bar{u} f$}

Kata al-da'if secara etimologi adalah lawan dari al-qawiy, yang berarti "lemah", hadis da'îf ini adalah hadis mard $\bar{u}$, yaitu hadis yang ditolak dan tidak dapat dijadikan hujah atau dalil dalam

\footnotetext{
${ }^{14}$ Yuslem, Ulumul, 163-164.

${ }^{15}$ Șubḥ̄̄ al-Ṣāliḥ, 'Ulūm al-Hadīì $\quad$ wa Muṣtalāḥuhu (Beirūt: Dār al-'Ilm li al-Malāyīn, 1973),141. Lihat juga M. Mushtafa 'Azami, Studies In Hadith Methodology and Literature, terj: A. Yamin, Metodologi Kritik Hadis (Jakarta: Pustaka Hidayah, 1992), 101-102.

${ }^{16} \mathrm{Al}-\mathrm{Khațīb}$, Ușūl, 303.
} 
menetapkan suatu hukum. ${ }^{17}$ Tetapi menurut M. Mustafa 'Azami, hadis da îf itu dapat dikelompokkan ke dalam dua bagian: yaitu hadis yang ditolak; tetapi masih bisa diterima, jika hadis tersebut mendapat dukungan kekuatan dari hadis lainnya. Bagian kedua adalah hadis yang ditolak secara total. ${ }^{18}$ Menurut Imam Abi 'Amar ibn al-Salah hadis $d a$ 'îf ialah: "Setiap hadishadis yang tidak terdapat padanya sifat hadis sahih dan tidak pula sifat-sifat hadis hasan maka dia disebut hadis $d a$ 'i $f$." 19

Imām Hāfiẓ Hasan al-Mas'ūdī memberikan definisi hadis da'îf sebagai hadis yang kehilangan satu syarat atau lebih dari hadis sahih atau hadis hasan."20 Menurut Imām al-Nawawī ketika mensyarah Șahīh Muslim, "hadis dạîf adalah hadis yang tidak mencukupi syaratsyarat hadis sahih dan hadis hasan, dan pembagiannya sangat banyak yaitu: hadis mauḍū', hadis maqlūb, syā̇̀, munkar, mu 'allal, dan mud̦țarib". 21

Dengan demikian, dapat disimpulkan bahwa hadis ${ }^{\prime} a^{\prime} i f$ adalah hadis yang tidak mencukupi syarat sahih maupun

\footnotetext{
${ }^{17}$ Yuslem, Ulumul, 236.

18، Azami, Studies, 102.

${ }^{19}$ Ibn al-Șalāḥ, 'Ulūm al-Hadìis, Ed. Nur al-
} Dīn 'Attar (Madinah: Al-Maktabah al-'Ilmiyyah,cet: 2, 1972), 37.

${ }^{20}$ Haâfiż Hasan Mas‘ūdī, Minḥatu al-Mugīis Fī al-Muștalāhal-Hadīis (Surabaya: Ahmad Nabni, t.th), 10.

${ }^{21}$ Muhạmmad Jamāl al-Dīn al-Qāsimī, Qawā'id al-Tahoīis Min Funūn Muștalāhal-Hadīs (Beirūt: Dār al-Kutub al-'Ilmiyyah, t.th.), 108. hasan, baik dari segi sanad maupun matannya, maka kekuatannya lebih rendah dibandingkan dengan hadis sahih dan hadis hasan. Dari keterangan di atas dapat diambil intisari bahwa hadis da îf memiliki beberapa kriteria yaitu:

a. Terputusnya perawi dalam satu jalur sanad hadis yang seharusnya bersambung.

b. Terdapat cacat ('illāt) dan kejanggalan (syużūz) pada diri seorang perawi atau matan dari hadis tersebut.

c. Diriwayatkan oleh orang yang tidak adil dan tidak dābit (kuat hafalan).

Ketidaksahihan suatu hadis tidak harus berkumpul semua kriteria di atas, namun jika ada salah satu di antaranya yang muncul, maka hadis tersebut sudah masuk dalam kategori da ‘ $i f .^{22}$ Jika dipahami lebih dalam, maka hadis da'îf (lemah) dapat terbagi menjadi dua macam, yaitu da îf sanad dan da'îf matan. Da'îf (lemah) sanad maksudnya sebuah hadis yang sanadnya tidak valid memenuhi kriteria (standarisasi diterimanya sebuah periwayatan) hadis sahih, seperti tidak bersambungnya para perawi yang meriwayatkan hadis pada jalur sanad serta terbukti rawinya tidak adil dan tidak kuat hafalan, tentunya keḍa 'îfan sanad dapat diketahui setelah melewati proses penelitian atau analisis kritik (takhrijj)

\footnotetext{
${ }^{22}$ Wahid, Studi, 118.
} 
terhadap perawi hadis, yang dilakukan oleh para kritikus yang memang pakar di bidang hadis. Adapun maksud dari da'îf matan ialah sebuah hadis yang matannya tidak memenuhi kriteria hadis sahih, atau dengan kata lain hadis tersebut da'if disebabkan karena matannya yang kontradiktif dengan Alquran, sejarah, akal dan ciri-ciri kenabian.

Dalam dari itu, menurut Ramli Abdul Wahid yang beliau kutip dari Șalāḥ al-Dīn bin Aḥmad al-Idlibī, beliau menyatakan bahwa salah satu syarat kesahihan matan hadis harus mencakup beberapa poin berikut ini:

1.) Sanadnya sahih (penentuan kesahihan sanad harus didahului dengan kegiatan takhìj al-ḥadīs dan dilanjutkan dengan kegiatan penelitian sanad hadis).

2.) Tidak bertentangan dengan hadis mutawātir atau hadis ahâad yang sahih.

3.) Tidak bertentangan dengan petunjuk Alquran (ayat-ayat yang muhkam)

4.) Sejalan dengan alur akal sehat

5.) Tidak bertentangan dengan indera dan realitas sejarah
6.) Susunan lafalnya sesuai dengan karakteristik pembicaraan atau ciriciri kenabian. ${ }^{23}$

Sebagaimana yang kita ketahui bahwa hadis da'if adalah hadis yang tidak diterima kehujahannya (mard $\bar{u} d)$, akan tetapi apabila ada sebuah hadis $d a$ 'îf, yang setelah diteliti ternyata keda īfannya terletak disanadnya, yang disebabkan oleh cacat pada diri seorang perawi, maka bukan berarti matannya tidak bisa digunakan lagi atau dengan kata lain dikenal dengan kaidah:

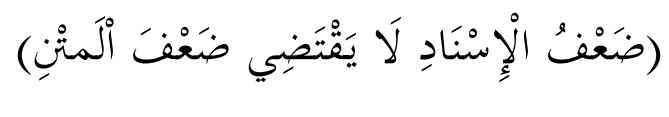

"Jika ada hadis yang lemah sanadnya disebabkan oleh cacat pada diri seorang perawi, maka matannya belum tentu da 'if (lemah)”.

Kaidah hadis semacam ini bisa digunakan dengan syarat:

a.) Mendapat dukungan kekuatan dari hadis lain yang senada matannya, diriwayatkan dari perawi (jalur sanad) yang lain, serta memiliki kualitas sama atau lebih baik dari jalur sanad yang pertama. Muhammad Jamāl alDīn al-Qāsimī mengatakan, "siapa saja yang melihat atau menemukan suatu hadis lemah sanadnya, maka hendaklah orang itu mengatakan hadis ini lemah berdasarkan sanad ini,

${ }^{23}$ Ramli Abdul Wahid, Ilmu-Ilmu Hadis (Bandung: Citapustaka Media Perintis, 2013), 110111. 
sedangkan matannya tidak lemah, karena boleh jadi hadis tersebut memiliki jalur sanad lain, yang lebih sahih dari jalur sanad pertama kecuali tidak ada jalur sanad yang lain atau hadis itu da'îf disertai dengan jelas keḍa 'îfannya (terlalu lemah)". ${ }^{24}$

b.) Perawinya tidak bersifat fasik, atau pendusta, ${ }^{25}$ bukan pula pemalsu hadis dan tidak dikenal sebagai orang yang fahusya galațhu (banyak salah) dan lalai, bukan al-muttahimina bil każib (dituduh berdusta), ${ }^{26}$ bukan ahli bidah serta bukan majḥūl 'ain.

c.) Keḍaīfannya tidak terlalu lemah. Pendapat ini disebutkan oleh Ibn Hajar, $^{27}$ seperti hadis mursal, ${ }^{28}$ mu'allal, ${ }^{29}$ mubham. ${ }^{30}$ Maka hadishadis yang tidak terlalu lemah tersebut masih bisa diterima (maqbūl) jika ada jalur sanad dari hadis yang lain, sedangkan hadis-hadis yang

${ }^{24}$ Al-Qāsimī, Qawā 'id, 121.

${ }^{25}$ Al-Qāsimī, Qawā iid, 109.

${ }^{26}$ Al-Qāsimī, Qawā id, 116.

${ }^{27}$ Al-Qāsimī, Qawā ìd, 116

${ }^{28}$ Hadis mursal ialah hadis yang perawinya adalah sahabat yang digugurkan (tidak disebut namanya). Lihat Wahid, al-Qāmūs, 156.

${ }^{29}$ Hadis mu'allal adalah hadis yang tampaknya akurat, padahal memiliki cacat yang tersembunyi pada $i s n \bar{a} d$, kadang-kadang ia terdapat dalam teks hadis itu sendiri, misalnya seorang ulama melakukan kekeliruan dalam mengutip atau melalaikan satu baris dalam mengutip. Al-Hakim membagi cacat ini ke dalam sepuluh jenis, buku yang paling terkenal adalah al- ilal karya Daruqutni. Lihat Metodologi Kritik Hadis, terj: A. Yamin, 110.

${ }^{30}$ Hadis yang pada matan atau sanadnya ada seseorang yang tidak disebut namanya. Wahid, alQāmūs, 134. sangat lemah seperti hadis mauḍ̄', hadis matrūk, ${ }^{31}$ dan hadis munkar ${ }^{32}$ maka tergolong mardūd (ditolak) bahkan tidak bisa dijadikan hujah. ${ }^{33}$

d.)Hadis-hadisnya memiliki syāhid dan mutābi ${ }^{34}$ Pendapat ini diberikan oleh al-Zarkasȳi. $^{35}$ Maksudnya hadis tersebut tidak hanya diriwayatkan dengan satu jalur sanad saja, karena bisa bertentangan dengan kaidahkaidah yang sudah dimaklumi, seperti hadis matrūk.

\section{I'tibār al-Hadīis}

I'tibār adalah menyertakan sanadsanad yang lain untuk suatu hadis tertentu, yang hadis itu pada bagian sanadnya tampak hanya terdapat seorang perawi saja, dan dengan menyertakan sanad-sanad yang lain tersebut akan dapat diketahui apakah ada periwayat yang lain ataukah tidak ada

\footnotetext{
${ }^{31}$ Hadis matrūk adalah hadis yang diriwayatkan oleh seorang perawi yang tertuduh dusta dalam hadis, atau menampakkan kefasikan dengan perbuatan atau perkataan, atau banyak lupa, atau banyak berandai-andai. Wahid, al-Qāmūs, 126.

${ }^{32}$ Hadis munkar adalah hadis yang di dalam sanadnya terdapat periwayat yang banyak melakukan kesalahan, lalai, atau jelas kefasikannya. Lihat al-Ṭaḥhān, Taysīr, 94. Lihat juga Wahid, alQāmūs, 154.

${ }^{33}$ Wahid, Studi, 115.

${ }^{34} M u t a \overline{b i} i^{`}$ sering juga disebut tābi` yaitu perawi yang berstatus pendukung pada perawi yang bukan sahabat Nabi. Syāhid adalah perawi yang berstatus pendukung yang berkedudukan sebagai dan untuk sahabat Nabi. Lihat M. Syuhudi Ismail, Metodologi Penelitian Hadis Nabi (Jakarta: Bulan Bintang, 1992), 52.

${ }^{35}$ Wahid, Studi, 115.
} 
untuk bagian sanad dari sanad hadis yang dimaksud. ${ }^{36}$ Di bawah ini adalah contoh i'tibār hadis yang lemah sanad tetapi matannya tidak lemah.

1. Di dalam Sunan al-Tirmiż̄̄, matan dan sanadnya adalah sebagai berikut:

حَلَّتنَّا أََمَدَ بن نصر النيسابوريّ وغير واحد قالوا: حدثنا أبو هُسسهِر عن إسماعيل بن عبدالله بن سمَّاعَة، عن الأوزعي، عن قُرَّة، عن الزُهرِي عن أبي سَاَمَة عن أبي هريرة قال: قال رسول

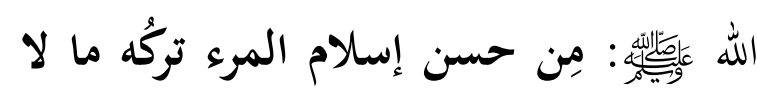
يعنيه.قال: هذا حديث غريب، لا نعرفه من

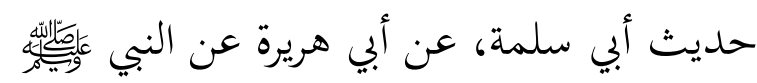
إلامن هذالوجهه

Kami (al-Tirmiż̄i) diceritakan oleh Ahmad bin Nașar an-Naisābūrī dan beberapa orang lainnya, mereka berkata "kami diceritakan oleh $\mathrm{Abu}$ Mushir dari Ismail bin Abdullah bin Sama'ah, dari al-Auza'i, dari Qurrah, dari al-Zuhri, dari Abu Salamah Dari Abu Hurairah, beliau berkata, Rasullah saw., bersabda, "Di antara kebaikan seorang muslim adalah meninggalkan hal-hal yang tidak bermanfaat baginya, Imam alTirmizi ber-komentar, "Ini adalah hadis garīb, kami tidak mengetahui hadis ini dari Abu Salamah dan dari Abu Hurairah dari Rasulullah Saw kecuali dari jalur ini". ${ }^{37}$
2. Di dalam Sunan Ibnu Mājah, matan dan sanadnya sebagai berikut:

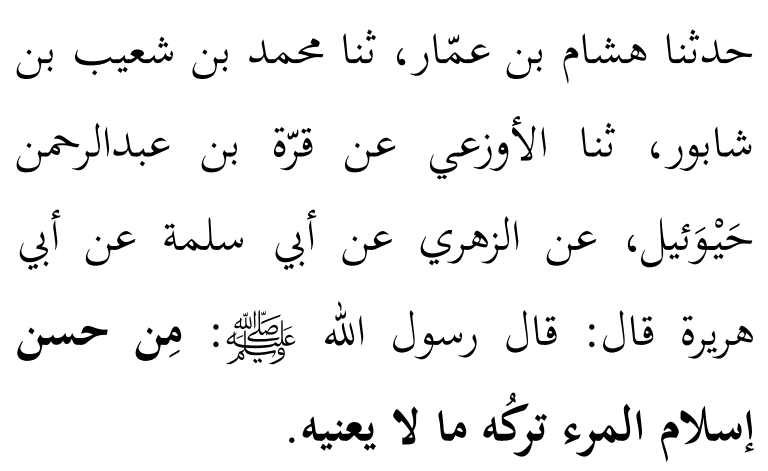

Kami (Ibnu Mājah) diceritakan oleh Hisyam bin Ummar, kami (Hisyam) diceritakan oleh Muhammad bin Syu'aib bin Syabur, kami (Muhammad) diceritakan oleh alAuza'i dari Qurrah bin Abdurahman Haiwail, dari al-Zuhri, dari Abu Salamah Dari Abu Hurairah, beliau berkata, Rasullah Saw bersabda "Di antara kebaikan seorang muslim adalah meninggalkan hal-hal yang tidak bermanfaat baginya".

3. Di dalam Muwatta' Imam Malik, sanad dan matannya sebagai berikut:

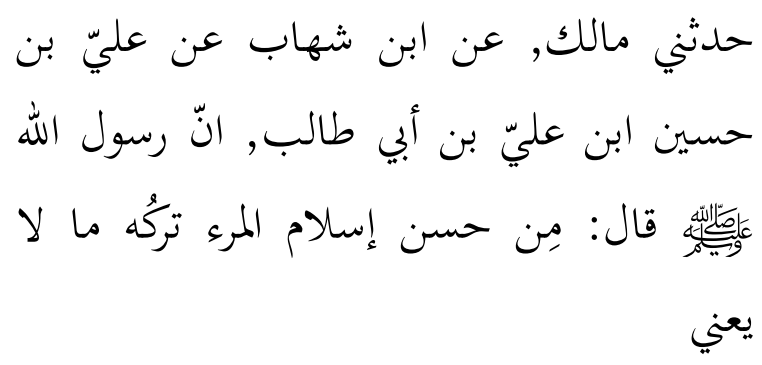

Malik bercerita kepada saya, dari Ibn Syihab dari Ali bin Husein Ibnu Ali bin Abi Talib, bahwasanya Rasulullah saw. pernah bersabda, "Di antara kebaikan seorang muslim adalah meninggalkan hal-hal yang tidak bermanfaat baginya". ${ }^{38}$

\footnotetext{
${ }^{38}$ Malik bin Anas, al-Muwatta' (Cairo: Dar al-Hadis, 2004), 478.
} 
4. Di dalam Musnad Imam Aḥmad, sanad dan matannya sebagai berikut:

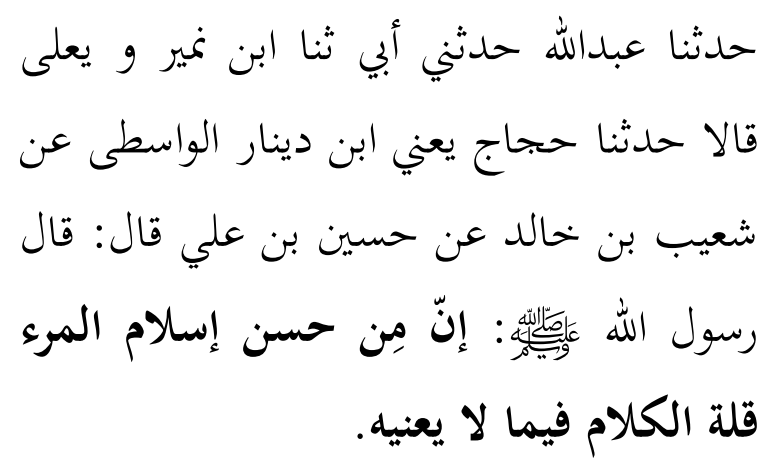

Artinya: Kami (Ahmad) diceritakan oleh Abdullah, saya (Abdullah) diceritakan oleh Ayah saya, kami diceritakan oleh Ibnu Numair dan Ya la, mereka berdua berkata, kami diceritakan oleh Hajjaj yaitu Ibnu Dinar al-Wasiti dari Syu'aib bin Khalid dari Husain bin Ali beliau berkata, Rasulullah saw. bersabda, "Di antara kebaikan seorang muslim adalah meninggalkan hal-hal yang tidak bermanfaat baginya". 39

Adapun hasil i'tibār dari sanad hadis di atas dapat dilihat pada skema di bawah sebagai berikut: Kita dengan berzikir dan berdoa kepada Allah swt. sebagaimana zikir dan doa yang diajarkan oleh Rasulullah saw di dalam hadisnya.

${ }^{39}$ Imam Ahmad bin Hanbal, Musnad Ahmad (Kairo: Dār al-Hadīì, t.th.), 201. 


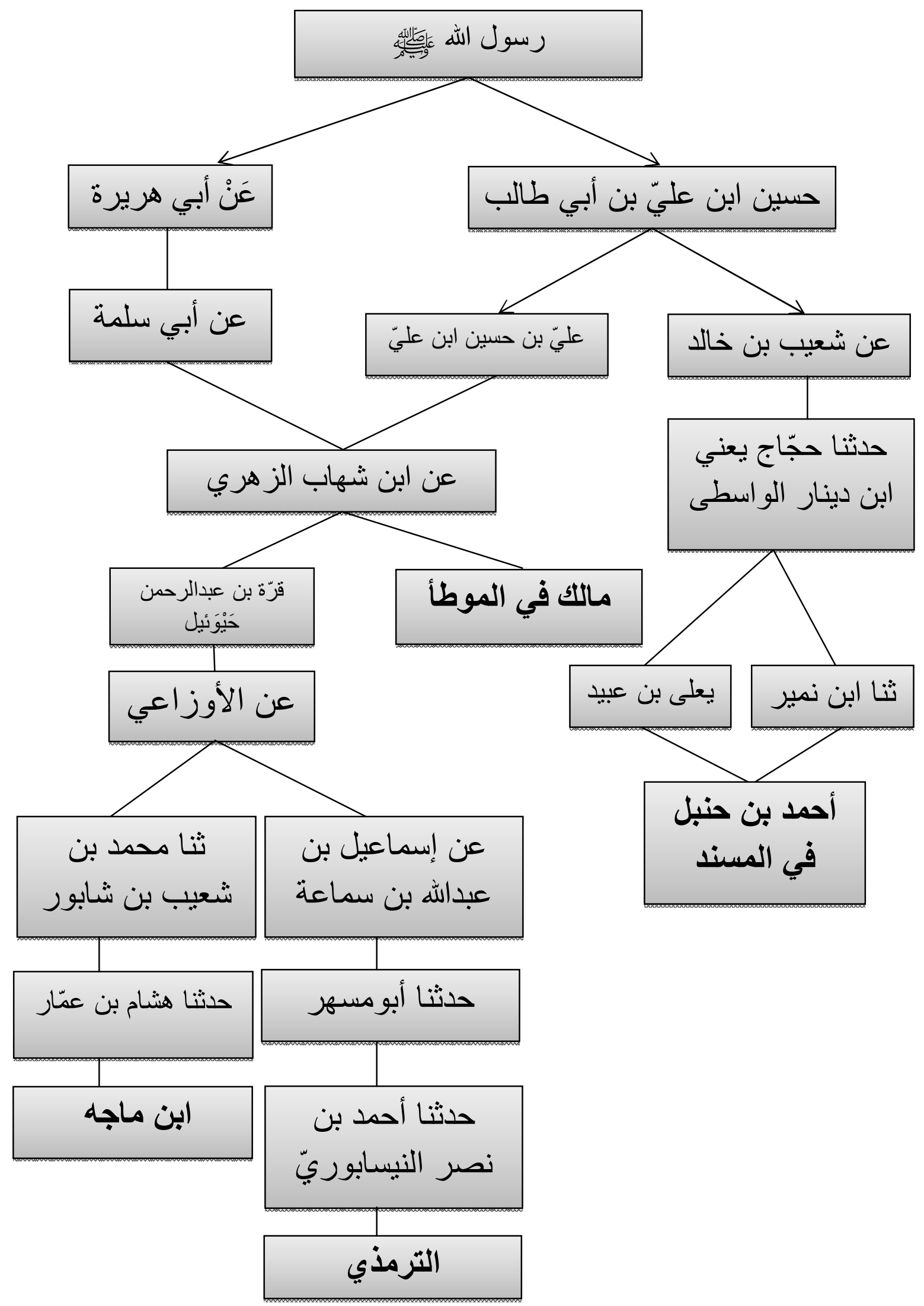


Dari hadis-hadis diatas setelah dibuat skemanya maka nampaklah bahwa Husain bin Ali bin Abi Thalib tersebut berperan sebagai syāhid terhadap hadis Abu Hurairah karena perawi pada tingkat sahabat dari hadis-hadis tersebut ada dua orang sahabat. Syāhid sangat diperlukan dalam proses penelitian hadis untuk menguatkan posisi suatu hadis dalam segi kuantitasnya. Sebuah hadis yang pada mulanya garīb (hanya diriwayatkan oleh seorang rawi) dapat naik tingkatannya menjadi hadis 'Azīz, hadis masyhūr atau bahkan hadis mutāwātir bila ada syāhid.

Posisi mutābi' dalam sebuah hadis sangat berpengaruh pada kualitas hadis itu sendiri. Karena ketika ada sebuah hadis yang dinilai dari segi sanad memiliki kekurangan, maka akan menyebabkan hadis tersebut tidak bisa mencapai derajat sahih atau hasan. Akan tetapi, ketika ditemukan hadis yang sama dari jalur lain, maka posisi hadis yang pertama bisa kuat dan bisa naik menjadi hadis șahih li gairih (apabila pertamanya ia hasan li żātih) berkat dukungan dari sanad lain tersebut. Hal ini karena substansi matannya dijustifikasi oleh faktor eksternal. Dan kekurangan pada salah satu perawi dapat dihilangkan dengan adanya bukti berupa hadis yang sama dan diriwayatkan dengan jalur yang berbeda.

Hadis yang jalur sanadnya diriwayatkan oleh Imam Tirmizi adalah lemah sanadnya, sedangkan hadis yang diriwayatkan oleh Imam Ahmad bin Hanbal, Imam Malik dan Ibnu Majah adalah hadis sahih.

Hadis dari $\mathrm{Mu}^{\prime} \mathrm{az}$ di atas, dapat kita ketahui bahwa di pertengahan sanad hadis tersebut terdapat beberapa pendukung berupa mutābi, yaitu Hannad adalah mutābi' bagi Muhammad ibn Basysyar, Waqi', 'Affan, Muhammad ibn Ja'far, Hafs ibn Umar dan Yahya ibn Hammad adalah mutābi' bagi "Abd al-Rahman ibn Mahdi. Hal tersebut semakin memperkuat kedudukan sanad hadis Mu'az ini dari pertengahan sanadnya sampai ke pangkal sanadnya. Seandainya salah satu hadis dari Mu'az iniberstatus da'îf, disebabkan karena da'îf sanad hadisnya, maka hadis itu bisa naik statusnya menjadi hasan li gairih berkat adanya mutābi' dan begitu juga seterusnya.

Maka di sinilah berlakunya kaidah, "lemahnya sanad tidak menentukan lemah pula matannya," apa lagi ada jalur periwayatan yang saling menguatkan satu sama lain, terlebih lagi jika jumlah turuq hadisnya beragam, maka status hadis yang lemah tadi berubah menjadi maqbūl, bahkan matan hadis tersebut masih bisa diselamatkan dengan melakukan 'i'tibār seperti di atas. Jika hadis tersebut ternyata didapati ada unsure syāhid dan mutābi'nya, maka status hadis itu bisa naik 
tingkatannya menjadi lebih tinggi dari sebelumnya, jika sebelumnya berstatus da'îf, maka bisa naik menjadi hasan li gairih (maqbūl).

\section{Kesimpulan}

Berdasarkan pemaparan di atas, dapat kita ambil kesimpulan bahwa sanad itu merupakan jalan penghubung antara perawi-perawi secara berurutan yang meriwayatkan matan (teks) hadis dari sumbernya yang pertama. Contohnya, Kami diceritakan oleh Aḥmad bin Nasar alNaisaburi dan orang lain, mereka berkata “Abu Mushir menceritakan kepada kami yang diriwayatkan dari Ismail bin Abdullah bin Sama'ah, dari al-Auza'i, dari Qurrah, dari al-Zuhri, dari Abu Salamah Dari Abu Hurairah, beliau berkata, Rasullah saw bersabda "Di antara kebaikan seorang muslim adalah meninggalkan hal-hal yang tidak bermanfaat baginya.

Adapun matan adalah lafal hadis yang mengandung makna (pengertian). Isnād ialah mengangkat hadis kepada yang mengatakannya (sumbernya), yaitu menjelaskan jalan matan dengan meriwayatkan hadis secara bersanad. Musnid adalah orang yang meriwayatkan hadis lengkap dengan sanadnya, baik ia menguasai seluk beluk tentang hadis atau hanya semata-mata meriwayatkan hadis tersebut.
Musnad juga memiliki beberapa pengertian di antaranya: hadis yang bersambung sanadnya dari awal sanad hingga akhir sanad sampai kepada Nabi saw., setiap hadis marfü' (riwayat yang disandarkan kepada Nabi) dengan sanad yang bersambung, hadis yang menerangkan rangkaian sanadnya serta semakna dengan pengertian sanad. Hadis $d a$ 'îf adalah hadis yang terputusnya perawi dalam satu jalur sanad hadis yang seharusnya bersambung, terdapat cacat ('illāt) dan kejanggalan

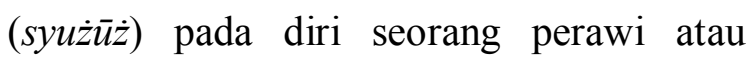
matan dari hadis tersebut, serta diriwayatkan oleh orang yang tidak adil dan tidak dābit.

Hadis da'îf yang disebabkan oleh lemahnya unsur periwayatan (jalur sanad suatu hadis), tidak serta-merta ditolak secara totaluntuk dijadikan hujah, sebab jika diteliti dari segi matannya bisa jadi hasilnya belum tentupula terindikasi lemah. Oleh karena itu, jika ada jalur periwayatan yang saling menguatkan satu sama lain, terlebih lagi jika jumlah țuruq hadisnya beragam, maka status hadis yang lemah tadi berubah menjadi maqbūl, bahkan matan hadis tersebut masih bisa diselamatkan dengan melakukan i'tibār yaitu dengan menghadirkan syāhid dan mutābi'-nya. Jika hadis tersebut ternyata didapati ada unsur syāhid dan mutābi '-nya, maka status hadis itu bisa naik tingkatannya menjadi lebih 
tinggi dari sebelumnya, jika sebelumnya berstatus da'iff, maka bisa naik menjadi hasan li gairih (maqbul). Dengan demikian, matan hadis tersebut masih bisa diaplikasikan untuk menetapkan suatu hukum, walaupun tidak sekuat hadis hasan li żātih. Demikian juga jika status suatu hadis sebelumnya bersifat hasan, maka hadis tersebut bisa naik tingkatanya menjadi șahịh li żātih.

\section{Daftar Pustaka}

Abū Dawūd, Sulaimān ibn al-Asy'aṡ al-Sijistānī. Sunan Abī Dāwūd. Beirūt: Dār al-Fikr, 1414 $\mathrm{H} / 1994$.

As-Siddieqy, T.M. Hasbi. Sejarah dan Pengantar Ilmu Hadis. Jakarta: Bulan Bintang, 1991.

'Azami, M. Mushtafa. Studies In Hadith Methodology and literature, terj: Yamin, A. Metodologi Kritik Hadis. Jakarta: Pustaka Hidayah, 1992.

al-Bukhārī, Muḥammad ibn Ismā‘̄il ibn Ismā‘n̄l ibn Ibrāhīm ibn Al-Mugīraḥ. Sahịh alBukhārī. Beirūt: Dār al-Fikr, 1981.

al-Dārimī, Abū Muḥammad Abu Allāh Abd al-Raḥmān ibn Baḥram. Sunan al-Dārimī. Beirūt: Dār al-Fikr, t.th.

Departemen Pendidikan dan Kebudayaan, Tim Penyusun Kamus. Kamus Besar Bahasa Indonesia. Edisi Kedua. Jakarta: Balai Pustaka, 1996.

Ḥasan Mas ‘ūdī, Ḥāfīz. Minḥatu al-Mugī̉ Fī al-Muștalāḥ al-Hadīs. Surabaya: Ahmad Nabni, t.th.

Ibn Ḥanbal, Aḥmad. Musnad al-Imām Aḥmad ibn Hanbal.Beirūt: Dār al-Fikr, t.th.

Ismail, M. Syuhudi. Metodologi Penelitian Hadis Nabi. Jakarta: Bulan Bintang, 1992. . Kaedah Kesahihan Sanad Hadis. Jakarta: Bulan Bintang, 1988.

Kas̄īr, Ibnu. al-Bais̉ al-Hadīis Syarh Ikhtiṣar 'Ulūm al-Hadīis’. Beirūt: Dār al-Fikr, t.th. al-Khațīb, M. 'Ajjāj. Ușūl al-Hadīs: 'Ulūmuhu wa Muṣtalāḥuhu. Beirūt: Dār al-Fikr, 1989. al-Naisaburiy, Muslim ibn al-Ḥajjāj ibn Muslim al-Qusyairīy. Șaḥ̄ḥ Muslim.Beirūt: Dār alFikr, 1414 H/1993.

al-Nasā’i, Abū 'Abd al-Raḥmān Aḥmad ibn Syu'aib. Sunan al-Nasā’i. Beirūt: Dār al-Fikr, $1415 \mathrm{H} / 1995$.

. Sunan al-Nasā'i al-Mujtabā. Mesir: Syirkah Maktabah al-Bābī al-Halabī, 1383 H/1964. 
al-Qāsimī, Muḥammad Jamāl al-Dīn. Qawā'id al-Taḥdīs Min Funūn Muștalaḥ al-Hadīs. Beirūt: Dār al-Kutub al-'Ilmiyyah, t.th.

al-Qazwin̄̄, Abū 'Abdullāh Muḥammad ibn Yazīd. Sunan Ibnu Mājaḥ, Ed. Al-Attar, Sidqī Jamīl. Beirūt: Dār al-Fikr, 1415 H/ 1995.

al-Rāzī, Muḥammad bin Ab̄̄ Bakr bin Abd al-Qādir. Mukhtār Al-Ṣihḥāh. Beirūt: Dār al-Fikr, 2003.

al-Ṣalāḥ, Ibn. 'Ulūm al-Hadīs, Ed. Nur ad-Din 'Attar. Madinạ̣: Al-Maktabat al-'Ilmiyyaḥ, 1972.

al-Ṣalih, Șubḥi. 'Ulūm al-Hadīswa Muștalāḥuhu.Beirūt: Dār al-'Ilm li al-Malāȳ̄n, 1973.

al-Ṭaḥānawī. Qawā 'id fì 'Ulūm al-Hadīs. T.t.: Tp, t.th.

al-Ṭaḥḥān, Mạ̣mūd. Taysīr Muștalaḥ al-Hadìs. T.t.: Tp, t.th.

al-Tirmizì.Sunan Al-Tirmizī. Beirūt: Dār al-Fikr, 1983.

Wahid, Ramli Abdul. al-Qāmūs al-Muhịṭ fì Ulūm al-Hadīs, Kamus lengkap Ilmu Hadis. Medan: Perdana Publishing, 2011. . Ilmu-Ilmu Hadis.Bandung: Citapustaka Media Perintis, 2013 . Studi Ilmu Hadis. Bandung: CitaPustaka Media Perintis, 2011.

Yuslem, Nawir. Metodologi Penelitian Hadis. Bandung: CV. Perdana Mulya Sarana, 2008 . Ulumul Hadis. Jakarta: PT. Mutiara Sumber Widya, 2010. 
LEMAH SANAD BELUM TENTU LEMAH MATAN

222 Vol. 1, No. 2, Juli-Desember 2018 M/1440 H 